\title{
Innovation ecosystem for SMES in ICT industry
}

Pooya Namaayande

Ph. D Candidate, Department of Industrial management, Faculty of Management, Science and Research Branch, Islamic Azad University, Tehran, Iran

p.namaayande@aftermail.ir

Abbas Khamseh

Assistant Professor, Department of Industrial management, Faculty of Management, Karaj Branch, Islamic Azad University, Karaj, Iran

a.khamseh@aftermail.ir

\section{Editor Científico: José Edson Lara}

Organização Comitê Científico

Double Blind Review pelo SEER/OJS

Recebido em 06.05.2019

Aprovado em 21.06.2019 


\begin{abstract}
Since in the today's economy world, the necessity of entrepreneurship in small and mediumsized enterprises is important in many countries in terms of employment creation, in this regard, attention to entrepreneurship and innovation in small and medium-sized (SME) enterprises, are the most effective factors in the development of economic and social systems of each country. The present study aims at identifying and defining the dimensions and components of the ecosystem of entrepreneurship and innovation in accordance with the requirements of the country in Iran, in order to develop and improve the strategies and policies for developing entrepreneurial technology in small and medium-sized enterprises. In this study, using an estimate from the entrepreneurship and innovative ecosystems and comparing it with the ecosystem of other countries with similar conditions to Iran, we will come up with a professional structure, including the common aspects of their models and criteria, and by examining the factors that play the vital role of innovation and entrepreneurship of Iranians, we will make the feasibility and design of the innovation ecosystem feasible in ICT industry as a strategic planning for the creation of an entrepreneurship and innovation ecosystem in SMEs of ICT industry. This study will try to prepare an entrepreneurship and innovation ecosystem with the help of information technology and encourage small and innovative business startups as well as innovation and entrepreneurship in an environment of entrepreneurship ecosystems based on digital innovation and communication and information technologies will be formed.
\end{abstract}

Keyword: entrepreneurship, innovation ecosystem, SME, ICT industry

\title{
Ecossistema de inovação para PME na indústria de TIC
}

\section{Resumo}

No mundo econômico de hoje a necessidade de empreendedorismo nas pequenas e médias empresas é importante em muitos países em termos de criação de emprego. A este respeito, a atenção ao empreendedorismo e à inovação nas pequenas e médias empresas (PME) são os fatores mais eficazes no desenvolvimento dos sistemas econômicos e sociais de cada país. $\mathrm{O}$ presente estudo visa identificar e definir as dimensões e componentes do ecossistema de empreendedorismo e inovação de acordo com as exigências do país no Irã, a fim de desenvolver e melhorar as estratégias e políticas para o desenvolvimento de tecnologia empreendedora em pequenas e médias empresas. empreendimentos. Neste estudo, usando uma estimativa do empreendedorismo e ecossistemas inovadores e comparando-o com o ecossistema de outros países com condições semelhantes ao Irã, vamos apresentar uma estrutura profissional, incluindo os aspectos comuns de seus modelos e critérios, e examinando os fatores que desempenham o papel vital de inovação e empreendedorismo dos iranianos, tornar a viabilidade e concepção do ecossistema de inovação viável na indústria de TIC como um planejamento estratégico para a criação de um ecossistema de empreendedorismo e inovação nas PME da indústria de TIC. Este estudo tentará preparar um ecossistema de empreendedorismo e inovação com a ajuda da tecnologia da informação e encorajar startups de negócios pequenos e inovadores, bem como inovação e empreendedorismo num ambiente de ecossistemas de empreendedorismo baseados em inovação digital e tecnologias de comunicação e informação.

Palavras-chave: empreendedorismo, ecossistema de inovação, PME, indústria de TIC 


\section{Ecosistema de innovación para PYMES en la industria de las TIC}

\section{Resumen}

En el mundo de la economía actual, la necesidad de emprender en las pequeñas y medianas empresas es importante en muchos países en términos de creación de empleo. En este sentido, la atención al emprendimiento y la innovación en las pequeñas y medianas empresas (PYME) son los factores más efectivos en el desarrollo de los sistemas económicos y sociales de cada país. El presente estudio tiene como objetivo identificar y definir las dimensiones y componentes del ecosistema de emprendimiento e innovación de acuerdo con los requisitos del país en Irán, a fin de desarrollar y mejorar las estrategias y políticas para desarrollar tecnología empresarial en pequeñas y medianas empresas empresas. En este estudio, utilizando una estimación del emprendimiento y ecosistemas innovadores y comparándolo con el ecosistema de otros países con condiciones similares a las de Irán, presentaremos una estructura profesional, que incluye los aspectos comunes de sus modelos y criterios, y examinando los factores que desempeñan el papel vital de la innovación y el espíritu empresarial de los iraníes, haremos posible la viabilidad y el diseño del ecosistema de innovación en la industria de las TIC como una planificación estratégica para la creación de un ecosistema de espíritu empresarial e innovación en las PYME de la industria de las TIC. Este estudio tratará de preparar un ecosistema de emprendimiento e innovación con la ayuda de la tecnología de la información y alentará la creación de pequeñas empresas innovadoras, así como la innovación y el emprendimiento en un entorno de emprendimiento basado en la innovación digital y las tecnologías de comunicación e información.

Palabra clave: emprendimiento, ecosistema de innovación, PYME, industria de las TIC

\section{Introduction}

Communication and information technologies are the most important driver of innovation and growth for the economies of countries around the world. Digital technologies and their related innovations are powerful and comprehensive and have a multifaceted and indirect impact on the economies of the countries. These technologies have led to the transformation of various industries and value chains and have reduced barriers to entry. These communications and information technologies have also created widespread intelligence in the market and the disappearance of industrial boundaries and the opening of new doors to the new generation of entrepreneurs and innovators (Pop et al., 2018). The challenge facing market leaders as well as small enterprises at the moment is to anticipate the changes that will face in 
the coming years and understand the full potential of digital technologies (Holgersson et al., 2017).

Businesses that stay connected to this digital world will simply be removed from the global marketplace (Rindfleisch et al., 2017). Entrepreneurship is known as a source of change in competitive conditions, which creates the conditions for innovation to overthrow. The entrepreneurial vision of entrepreneurship assumes that entrepreneurs, when they create new industries, are abolishing certain industries. This view is especially useful for understanding digital entrepreneurship because digital media and information technology have created new conditions for communication as well as new opportunities for business models while hitting the old industry (Scaringella, and Radziwon, 2018). Entrepreneurship and innovation are critical factors for long-term sustainability of e-commerce and e-commerce. In the e-business environment, there is a higher level of technical uncertainty and a fast rate of technology innovation. Technology innovation is driving economic growth, the globalization of markets, the competitiveness of companies and the standard of a country's life. Therefore, entrepreneurship is a key element in a new economy in which, without entrepreneurs, many new economic activities are not capable of successful implementation (Usman et al., 2018). . SMEs face the inherent tension of depending on external partners to complement their internal innovation activities while having limited resources to manage such open innovation processes. Given the importance of collaborative efforts between multiple stakeholders, we address the open innovation challenges from the SME perspective at the business-ecosystem level. SMEs are crucial catalysts of both developed and developing economies, accounting for over $99 \%$ of all businesses and more than $60 \%$ of all jobs created, as well as important sources of innovation (Muller et al., 2015).

\section{Theoretical foundation}

\subsection{Advantages of Innovation}

Innovation offers many benefits to companies active in this field, including reducing the cost of research and development, the potential for improvement in development productivity, customer participation in the development process, increasing the accuracy for market research and target customers, the combination of internal and external innovation and the potential for network marketing (Arabiun and Shaye Sani, 2016). 


\subsection{Disadvantages of Innovation}

The implementation of a model of innovation naturally faces a number of risks and challenges, including the possibility of disclosing information that it does not intend to share, the potential for loss of competitive advantage by organizations as a result of revealing their intellectual property, increasing the complexity of innovation control and regulation, and How participants participate in a project and the need to develop a tool for identifying the correctness and combination of external innovation (Arabiun and Shaye Sani, 2016).

\subsection{Open innovation models}

\section{Product platform}

This approach involves the development and introduction of a product under development, in order to provide a framework for access, customization and exploitation. Its goal is to develop product capabilities to increase product value for all parties involved.

\section{Idea tournament}

This model involves implementing and launching a system that encourages competition through successful rewards strategies. This approach allows organizations to make cheap access to a large number of new ideas, while also providing a deeper insight into customer requirements.

\section{Immerse in the customer}

This technique involves close and extensive interaction with the client through its hosting or through interaction with the organization's staff. In this way, organizations use customer information and data and lead customers to participate in the design and development of products.

\section{Designing and developing common products}

As with the product platform approach, the organization collaborates with its product development partners. The difference between this method and the first method is that there is a framework for cooperation and interaction, and the host organization will have the necessary controls and supervision in this regard. This method will allow more control and oversight to the organization, and will make products faster, while reducing costs for product development. 


\section{Innovation networks}

Similarly to the idea tournament, an organization uses a network of colleagues in the design process with rewards in the form of a motive. The difference is due to the fact that a network of colleagues is used to develop a solution to identify problems (Bogers et al., 2017).

\subsection{Small and medium-sized enterprises (SME)}

Due to the fact that the field of research is the ecosystem of entrepreneurship for small and medium-sized enterprises, we will see SMEs as a major area in the market ecosystem, and include factors such as financial and non-financial support, macro and micro support and reform. We consider political recovery and capacity building and the creation of appropriate business and family-friendly platforms as criteria for the success of SMEs (Kapoor and Adner, 2015).

Most SMEs lack technical experience, most of them lack sufficient capital to achieve technical success, suffer from inadequate organizational planning, and many of them with their larger counterparts in the product range are different from the customer service available. SME with a small management group, usually one or two, are heavily influenced by the personal attributes of their staff, they do not have much control over their environment and have a great desire to be independent. The unique features we are considering for SMEs are: SMEs have less control over the external environment than large businesses and therefore face more uncertainty and face greater risks than large business-related businesses because their failure rate is higher and are unwilling to risk and have a small, centralized management with a short term perspective. There is a disturbance of family values in their decision-making processes (Saguy and Sirotinskaya, 2014).

SME owners have a great influence on decision making processes. The decision-making process in SMEs is intuitive and not based on detailed planning and extensive study. SME owners often refuse to provide information to their colleagues and have a strong desire for independence, and prevent the business risks that affect autonomy and have poor management skills (Theyel, 2013).

SMEs are reluctant to allocate information technology spending, and they do not use much of this technology and face the problem of accessing financial resources and other resources, therefore have less resources and unofficial and inappropriate processes for planning and maintaining records and are not able to compete with their larger counterparts and are not interested in a large market share and are product-based, but large business-based The customer 
(Wynarczyk et al., 2013). SMEs have a limited market share. Therefore, they are heavily reliant on a number of customers and have limited product / service, lacking technical knowledge and expert personnel, and do not provide adequate training for IT staff (Verbano et al., 2015).

\subsection{Innovation and startup}

Startups are usually based on innovative ideas. In fact, an individual or creative and innovative person is ideally looking for ways to monetize the idea and mass production of products or services based on it. Innovations in startups show themselves in the form of market innovations, or product innovations, or in the form of single-startups (Giudici and RossiLamastra, 2018).

An ecosystem consisting of a large part of corporate and public sector innovation, along with research, budget, customers, research and innovation innovations, forms the ecosystem of innovation and, in the meantime, with the help of supporters and service providers and Achieving new sources of innovative start-ups will increase dramatically, and we will see the transition and transformation of the innovation ecosystem to the startup ecosystem (Anderson et al., 2018).

\subsection{Innovation Ecosystem in Small and Medium Enterprises (SEMs)}

By studying the development of the entrepreneurial ecosystem, it was urgently felt that ICT-equipped ecosystems such as IT and ICT, such as innovation ecosystems and IP startups, were felt. Therefore, to form a comprehensive system for the ecosystem of innovation and its relationship with other ecosystems, it eventually led to the formation of an ecosystem for innovation with six realms (Holgersson et al., 2017). The ecosystem's connection to SME is linked to the formation of a cluster of business that, if their activities are inclined to innovate and create new ones, become the core of the ecosystem of innovation, because these firms and there are different industries in which the development of technology and innovation takes shape, so in the first step we must focus on assessing and improving the power of technology and innovation in the firms. Therefore, attention to small and medium-sized enterprises with technology-based and knowledge-based foundations that play a key role in creating knowledge and technology in knowledge-based economies can play the leading role and direction of technology development in a set of subset businesses and in a large volume of economics shape the country. Except for those free-market, corporate, hubs and social, digital, and educational 
sectors completing the design of the ecosystem of innovation, we looked at our research (Brunswicker and Van de Vrande, 2014).

\section{Research background}

Ndemo (2016) discussed innovation and entrepreneurship under three main headings: the practice of innovation (the means by which entrepreneurs exploit change as an opportunity for a new business or service); the practice of entrepreneurship (the institution as the carrier of entrepreneurship); and entrepreneurial strategies (the management required to bring an innovation to market successfully). He argued that systematic innovation involves the purposive search for sources of innovation, referring to these sources as 'windows' of opportunity. ICTs, and specifically mobile platforms, have become the windows of opportunity in Africa that will bring about inclusive innovation (Ndemo, 2016).

Dong-1l (2017) investigates an underexplored significant area of research on the relationship between IoT attributes and innovation paths. The findings provide profound theoretical and practical implications. To the best of the author's knowledge, it is the first attempt to link disruptive and open IoT attributes to innovation paths of IoT-SMEs. The results provide directions for pursuing effective innovation in responding to the IoT market for sustainable growth (Dong-1l Shin, 2017).

Agnieszka and Marcel (2018) present an inductive case study of a particular regional ecosystem and focus on the inter-organizational collaboration between SMEs and other stakeholders in the ecosystem. They identify a particular set of challenges for the SMEs due to the misalignment between their business model and that of their ecosystem. Specific findings include the link between innovation type expressed by diverging understandings of the notion of innovation across the ecosystem and the innovation form, which should be organized and managed on multiple levels of analysis (SME, inter-organizational, and ecosystem). These findings highlight specific attention points for managing and developing open innovation in a regional business ecosystem, and they contribute both to the business-ecosystem literature as well as open innovation literature (Radziwon and Bogers, 2018).

\section{Research methodology}

The present research is applied in terms of purpose and descriptive in terms of collecting data and is considered as a field study .The method of conducting research is survey and one of its most important features is the ability to generalize the results .After studying the relevant 
texts and reviewing the literature of the research, according to the researchers, the evaluation indicators were developed .

The statistical population of the research is Iran's small and medium-sized enterprises in ICT industry.

Descriptive statistics were also used to analyze demographic questions. Then, using statistical tests, data analysis was performed using SPSS-22 software .Finally, the analytic hierarchy process (AHP) was used to rank the factors affecting open innovation.

\subsection{Research conceptual model:}

The following figure depicts the conceptual framework of this research. According to the explanations presented in the literature section, in order to measure the impact of the effective factors of innovation ecosystem on the effectiveness of small and medium-sized enterprises in ICT industry, the following conceptual framework has been used.

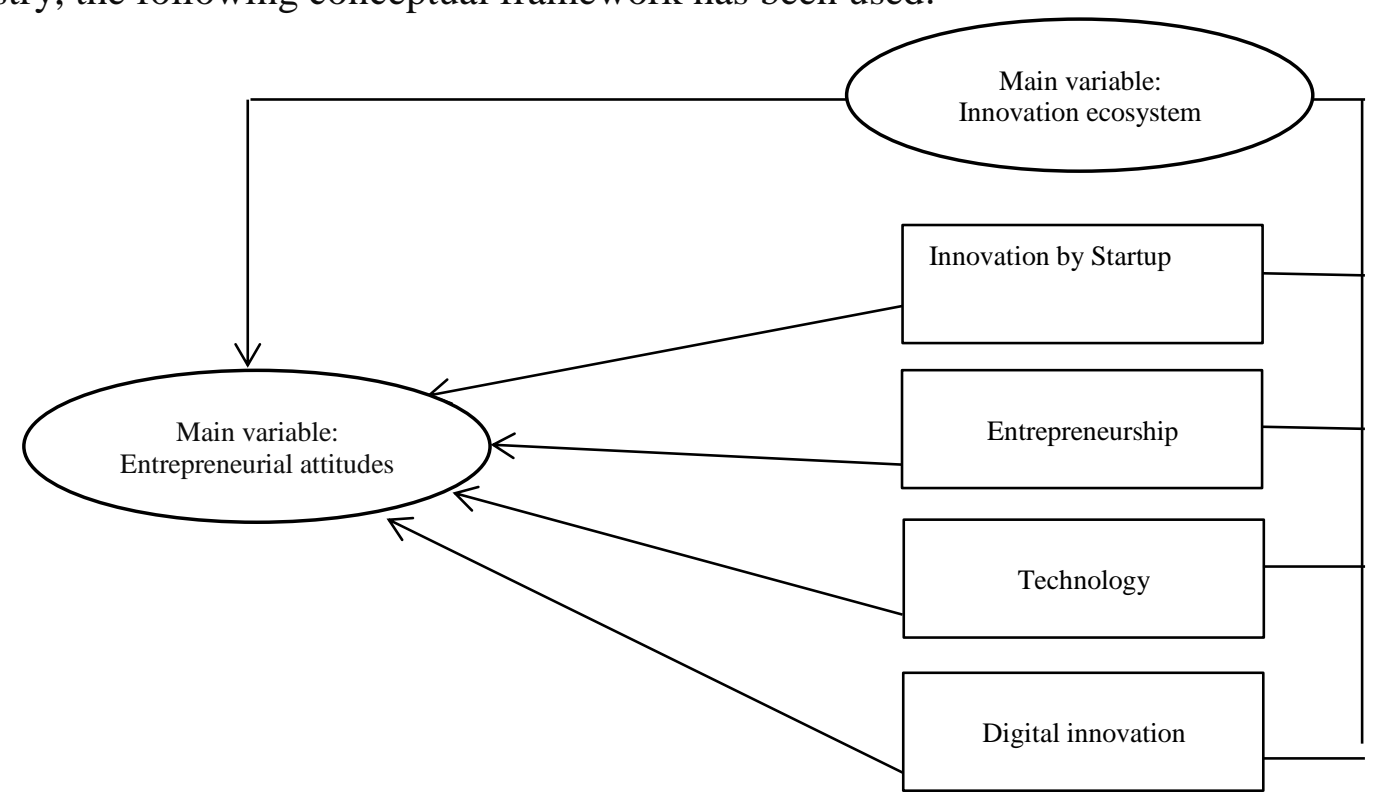

Figure 1: Conceptual Model

\section{Results}

\subsection{Data normality test}

In order to determine the appropriate type of test for data analysis, it is necessary to first examine the normal distribution of data. If the data have a normal distribution, then the parametric test is used and otherwise the nonparametric tests are used. In this test, the $\mathrm{H} 0$ is the normal distribution of data. The results of the Kolmogorov-Smirnov test show that the 
significance level for all variables is higher than 0.05 . Therefore the data are subject to normal distribution (Table 1).

Table 1

The Kolmogorov-Smirnov Test

\begin{tabular}{|l|c|l|}
\hline \multicolumn{1}{|c|}{ Variables } & Significance Level & \multicolumn{1}{c|}{ Result } \\
\hline Innovation by Startup & 0.332 & H0 confirmed (data distribution is normal) \\
\hline Entrepreneurship & 0.087 & H0 confirmed (data distribution is normal) \\
\hline Technology & 0.150 & H0 confirmed (data distribution is normal) \\
\hline Digital innovation & 0.198 & H0 confirmed (data distribution is normal) \\
\hline
\end{tabular}

\subsection{Pearson Correlation Coefficient}

Findings of Table 2 show that the significance levels between variables are less than 0.05 , so Pearson correlation coefficient between the variables is significant.

Table 2

Pearson Correlation Coefficient

\begin{tabular}{|c|c|c|}
\hline \multirow[t]{2}{*}{ Variables } & \multicolumn{2}{|c|}{$\begin{array}{c}\text { Statistical index } \\
\end{array}$} \\
\hline & $\begin{array}{l}\text { Correlation Coefficient } \\
(\mathrm{r})\end{array}$ & Significance level \\
\hline Innovation by Startup & $0.477 * *$ & 0.002 \\
\hline Entrepreneurship & $0.550 * *$ & 0.000 \\
\hline Technology & $0.602 * *$ & 0.001 \\
\hline Digital innovation & $0.598 * *$ & 0.001 \\
\hline $\begin{array}{l}0.01<\mathrm{p} \\
* * \text { all correlations are }\end{array}$ & nt at a 0.05 level of sig & cance \\
\hline
\end{tabular}

According to table 2, the significance of the correlation coefficient was below 0.05 for all of the research variables, so, research variables were significant.

\subsection{Hypothesis testing}

\subsubsection{First hypothesis testing:}

H0: Innovation by startup had not significant effect on the small and medium-sized enterprises in ICT industry.

H1: Innovation by startup had significant effect on the small and medium-sized enterprises in ICT industry. 
Table 3

Regression model fitness of first hypothesis

\begin{tabular}{|c|c|c|c|c|}
\hline Model & $\begin{array}{c}\text { Correlation } \\
\text { coefficient }\end{array}$ & $\begin{array}{c}\text { Coefficient of } \\
\text { determination }\end{array}$ & $\begin{array}{c}\text { Adjusted coefficient } \\
\text { of determination }\end{array}$ & $\begin{array}{c}\text { Standard error of } \\
\text { estimation }\end{array}$ \\
\hline 1 & 0.477 & 0.228 & 0.221 & 0.41246 \\
\hline
\end{tabular}

According to the table above, the coefficient of determination shows that the resulting model, explaining 0.228 percent change small and medium-sized enterprises in ICT industry.

Because it does not consider the degree of freedom therefore, the adjusted coefficient of determination for this purpose used is equal to 0.221 percent.

\section{Table 4}

Significance of regression by $\mathrm{F}$ test

\begin{tabular}{|l|c|c|c|c|c|}
\hline \multicolumn{1}{|c|}{ Model } & $\begin{array}{c}\text { Sum of } \\
\text { squares }\end{array}$ & $\begin{array}{c}\text { Degrees of } \\
\text { freedom }\end{array}$ & Root mean & F statistic & $\begin{array}{c}\text { Significance } \\
\text { level }\end{array}$ \\
\cline { 1 - 4 } Regression & 6.171 & 1 & 6.171 & 36.272 & 0.000 \\
\cline { 1 - 3 } Remaining & 20.926 & 123 & 0.170 & & \\
\hline Total & 27.096 & 124 & & & \\
\hline
\end{tabular}

According to above table of variance analysis, the Fisher test is equal to 36.272 which given the error level is less than 0.05 and it can be said that the goodness of fit of the regression model related to the effect of innovation by startup features on the development of entrepreneurial attitudes in the small and medium-sized enterprises in ICT industry is confirmed.

\section{Table 5}

Calculation of two variables regression equation

\begin{tabular}{|l|c|c|c|c|c|}
\hline \multicolumn{1}{|c|}{ Model } & \multicolumn{2}{|c|}{ Non standardized coefficients } & $\begin{array}{c}\text { Standardized } \\
\text { coefficients }\end{array}$ & T statistic & $\begin{array}{c}\text { Significance } \\
\text { level }\end{array}$ \\
\hline & B & $\begin{array}{c}\text { Standard } \\
\text { error }\end{array}$ & Beta & & \\
\hline Constant & 1.804 & 0.345 & 0.477 & 5.226 & 0.000 \\
\cline { 1 - 3 } \cline { 5 - 6 } Innovation by startup & 0.532 & 0.088 & & 6.023 & 0.000 \\
\hline
\end{tabular}

Regression model is displayed as follows: Innovation by Startup $\times 0.352+1.804=$ entrepreneurial attitudes in the small and medium-sized enterprises in ICT industry 


\subsubsection{Second hypothesis testing:}

H0: Entrepreneurship had not significant effect on the small and medium-sized enterprises in ICT industry.

H1: Entrepreneurship had significant effect on the small and medium-sized enterprises in ICT industry.

Table 6

Regression model fitness of second hypothesis

\begin{tabular}{|c|c|c|c|c|}
\hline Model & $\begin{array}{c}\text { Correlation } \\
\text { coefficient }\end{array}$ & $\begin{array}{c}\text { Coefficient of } \\
\text { determination }\end{array}$ & $\begin{array}{c}\text { Adjusted coefficient } \\
\text { of determination }\end{array}$ & $\begin{array}{c}\text { Standard error of } \\
\text { estimation }\end{array}$ \\
\hline 1 & 0.354 & 0.125 & 0.118 & 0.43897 \\
\hline
\end{tabular}

According to the table above, the coefficient of determination shows that the resulting model, explaining 0.125 percent change in small and medium-sized enterprises in ICT industry. Because it does not consider the degree of freedom therefore, the adjusted coefficient of determination for this purpose used is equal to 0.118 percent.

\section{Table 7}

Significance of regression by $F$ test

\begin{tabular}{|l|c|c|c|c|c|}
\hline \multicolumn{1}{|c|}{ Model } & $\begin{array}{c}\text { Sum of } \\
\text { squares }\end{array}$ & $\begin{array}{c}\text { Degrees of } \\
\text { freedom }\end{array}$ & Root mean & F statistic & $\begin{array}{c}\text { Significance } \\
\text { level }\end{array}$ \\
\hline Regression & 3.395 & 1 & 3.395 & 17.618 & 0.000 \\
\cline { 1 - 3 } Remaining & 23.701 & 123 & 0.193 & & \\
\hline Total & 27.096 & 124 & & & \\
\hline
\end{tabular}

According to above table of variance analysis, the Fisher test is equal to 17.618 which given the error level is less than 0.05 and it can be said that the goodness of fit of the regression model related to the effect of entrepreneurship features on the development of entrepreneurial attitudes in the small and medium-sized enterprises in ICT industry.

Table 8

Calculation of two variables regression equation

\begin{tabular}{|l|c|c|c|c|c|}
\hline \multirow{2}{*}{ Model } & \multicolumn{2}{|c|}{ Non standardized coefficients } & $\begin{array}{c}\text { Standardized } \\
\text { coefficients }\end{array}$ & T statistic & $\begin{array}{c}\text { Significance } \\
\text { level }\end{array}$ \\
\cline { 2 - 4 } & B & standard error & Beta & & \\
\hline Constant & 2.510 & 0.327 & 0.354 & 7.686 & 0.000 \\
\hline Entrepreneurship & 0.344 & 0.082 & & 4.197 & 0.000 \\
\hline
\end{tabular}


Regression model is displayed as follows:

Entrepreneurship $\times 0.344+2.510=$ entrepreneurial attitudes in the small and medium-sized enterprises in ICT industry

\subsubsection{Third hypothesis testing}

H0: Technology had not significant effect on the small and medium-sized enterprises in ICT industry.

H1: Technology had significant effect on the small and medium-sized enterprises in ICT industry.

Table 9

Regression model fitness of third hypothesis

\begin{tabular}{|c|c|c|c|c|}
\hline Model & $\begin{array}{c}\text { Correlation } \\
\text { coefficient }\end{array}$ & $\begin{array}{c}\text { Coefficient of } \\
\text { determination }\end{array}$ & $\begin{array}{c}\text { Adjusted coefficient } \\
\text { of determination }\end{array}$ & $\begin{array}{c}\text { Standard error of } \\
\text { estimation }\end{array}$ \\
\hline 1 & 0.292 & 0.086 & 0.078 & 0.44883 \\
\hline
\end{tabular}

According to the table above, the coefficient of determination shows that the resulting model, explaining 0.086 percent change in small and medium-sized enterprises in ICT industry. Because it does not consider the degree of freedom therefore, the adjusted coefficient of determination for this purpose used is equal to 0.78 percent.

\section{Table 10}

Significance of regression by $\mathrm{F}$ test

\begin{tabular}{|c|c|c|c|c|c|}
\hline Model & $\begin{array}{c}\text { Sum of } \\
\text { squares }\end{array}$ & $\begin{array}{c}\text { Degrees of } \\
\text { freedom }\end{array}$ & Root mean & F statistic & $\begin{array}{c}\text { Significance } \\
\text { level }\end{array}$ \\
\hline Regression & 2.318 & 1 & 2.318 & 11.505 & 0.001 \\
\cline { 1 - 3 } Remaining & 24.779 & 123 & 0.201 & & \\
\hline Total & 27.096 & 124 & & & \\
\hline
\end{tabular}

According to above table of variance analysis, the Fisher test is equal to 11.505 which given the error level is less than 0.05 and it can be said that the goodness of fit of the regression model related to the effect of technology features on the development of entrepreneurial attitudes in the small and medium-sized enterprises in ICT industry is confirmed. 


\section{Table 11}

Calculation of two variables regression equation

\begin{tabular}{|l|c|c|c|c|c|}
\hline \multirow{2}{*}{ Model } & \multicolumn{2}{|c|}{ Non standardized coefficients } & $\begin{array}{c}\text { Standardized } \\
\text { coefficients }\end{array}$ & \multirow{2}{*}{ T statistic } & $\begin{array}{c}\text { Significance } \\
\text { level }\end{array}$ \\
\cline { 2 - 5 } & B & standard error & Beta & & 0.000 \\
\hline Constant & 2.771 & 0.327 & 0.292 & 8.476 & 0.001 \\
\hline Technology & 0.275 & 0.081 & & 0.392 & 0.00 \\
\hline
\end{tabular}

Regression model is displayed as follows:

Technology $\times 0.275+2.771=$ entrepreneurial attitudes in the small and medium-sized enterprises in ICT industry

\subsubsection{Fourth hypothesis testing:}

H0: Digital innovation had not significant effect on the small and medium-sized enterprises in ICT industry.

H1: Digital innovation had significant effect on the small and medium-sized enterprises in ICT industry.

\section{Table 12}

Regression model fitness of fourth hypothesis

\begin{tabular}{|c|c|c|c|c|}
\hline Model & $\begin{array}{c}\text { Correlation } \\
\text { coefficient }\end{array}$ & $\begin{array}{c}\text { Coefficient } \\
\text { of } \\
\text { determination }\end{array}$ & $\begin{array}{c}\text { Adjusted coefficient } \\
\text { of determination }\end{array}$ & $\begin{array}{c}\text { Standard error of } \\
\text { estimation }\end{array}$ \\
\hline 1 & 0.425 & 0.181 & 0.174 & 0.42484 \\
\hline
\end{tabular}

According to the table above, the coefficient of determination shows that the resulting model, explaining 0.181 percent change in small and medium-sized enterprises in ICT industry.

Because it does not consider the degree of freedom therefore, the adjusted coefficient of determination for this purpose used is equal to 0.174 percent.

Table 13

Significance of regression by $F$ test

\begin{tabular}{|l|c|c|c|c|c|}
\hline \multicolumn{1}{|c|}{ Model } & $\begin{array}{c}\text { Sum of } \\
\text { squares }\end{array}$ & $\begin{array}{c}\text { Degrees of } \\
\text { freedom }\end{array}$ & Root mean & F statistic & $\begin{array}{c}\text { Significance } \\
\text { level }\end{array}$ \\
\cline { 1 - 4 } Regression & 4.896 & 1 & 4.896 & 27.127 & 0.000 \\
\cline { 1 - 3 } Remaining & 22.200 & 123 & 0.180 & & \\
\hline Total & 27.096 & 124 & & & \\
\hline
\end{tabular}


According to above table of variance analysis, the Fisher test is equal to 27.127 which given the error level is less than 0.05 and it can be said that the goodness of fit of the regression model related to the effect of digital innovation features on the development of entrepreneurial attitudes in the small and medium-sized enterprises in ICT industry is confirmed.

\section{Table 14}

Calculation of two variables regression equation

\begin{tabular}{|c|c|c|c|c|c|}
\hline \multirow{2}{*}{ Model } & \multicolumn{2}{|c|}{ Non standardized coefficients } & $\begin{array}{c}\text { Standardized } \\
\text { coefficients }\end{array}$ & T statistic & $\begin{array}{c}\text { Significance } \\
\text { level }\end{array}$ \\
\cline { 2 - 4 } & B & Standard error & Beta & & \\
\hline Constant & 2.610 & 0.245 & 0.425 & 10.643 & 0.000 \\
\hline Digital innovation & 0.338 & 0.065 & & 5.208 & 0.001 \\
\hline
\end{tabular}

Regression model is displayed as follows:

Digital innovation $\times 0.338+2.610=$ entrepreneurial attitudes in the small and medium-sized enterprises in ICT industry

\subsubsection{Main hypothesis testing}

H0: Innovation ecosystem had not a significant effect on entrepreneurial attitudes in the organization.

H1: Innovation ecosystem had a significant effect on entrepreneurial attitudes in the organization.

Table 15

regression model fitness of main hypothesis

\begin{tabular}{|c|c|c|c|c|}
\hline Model & $\begin{array}{c}\text { Correlation } \\
\text { coefficient }\end{array}$ & $\begin{array}{c}\text { Coefficient of } \\
\text { determination }\end{array}$ & $\begin{array}{c}\text { Adjusted coefficient } \\
\text { of determination }\end{array}$ & $\begin{array}{c}\text { Standard error of } \\
\text { estimation }\end{array}$ \\
\hline 1 & 0.501 & 0.251 & 0.245 & 0.40629 \\
\hline
\end{tabular}

According to the table above, the coefficient of determination shows that the resulting model, explaining 0.251 percent change in small and medium-sized enterprises in ICT industry.

Because it does not consider the degree of freedom therefore, the adjusted coefficient of determination for this purpose used is equal to 0.245 percent. 
Table 16

Significance of regression by $\mathrm{F}$ test

\begin{tabular}{|c|c|c|c|c|c|}
\hline Model & $\begin{array}{c}\text { Sum of } \\
\text { squares }\end{array}$ & $\begin{array}{c}\text { Degrees of } \\
\text { freedom }\end{array}$ & Root mean & F statistic & $\begin{array}{c}\text { Significance } \\
\text { level }\end{array}$ \\
\cline { 1 - 3 } Regression & 6.793 & 1 & 6.793 & \multirow{2}{*}{41.149} & 0.000 \\
\cline { 1 - 3 } Remaining & 20.304 & 123 & 0.165 & & \\
\hline Total & 27.096 & 124 & & \\
\hline
\end{tabular}

According to above table of variance analysis, the Fisher test is equal to 41.149 which given the error level is less than 0.05 and it can be said that the goodness of fit of the regression model related to the effect of innovation ecosystem features on the development of entrepreneurial attitudes in the small and medium-sized enterprises in ICT industry is confirmed.

\section{Table 17}

Calculation of two variables regression equation

\begin{tabular}{|c|c|c|c|c|c|}
\hline \multirow{2}{*}{ Model } & \multicolumn{2}{|l|}{ Non standardized coefficients } & $\begin{array}{c}\text { Standardized } \\
\text { coefficients }\end{array}$ & T statistic & $\begin{array}{c}\text { Significance } \\
\text { level }\end{array}$ \\
\cline { 2 - 4 } & $\mathrm{B}$ & standard error & Beta & & \\
\hline Constant & 1.488 & 0.373 & 0.501 & 3.985 & 0.000 \\
\hline Innovation ecosystem & 0.612 & 0.095 & & 6.415 & 0.001 \\
\hline
\end{tabular}

Regression model is displayed as follows:

Innovation ecosystem $\times 0.612+1.488=$ entrepreneurial attitudes in the small and medium-sized enterprises in ICT industry.

\section{Conclusion}

Achieving a knowledge-based economy and boosting production and entrepreneurship requires the creation of innovation and innovation ecosystem based on ICTs at the local and national levels. The first step in creating such ecosystems is to design a conceptual framework for them. This issue becomes more important in Iran, not only such conceptual designs have not been developed; there is not even a study on the innovation ecosystem and entrepreneurship based on ICT. The current era of accelerating change is unpredictable. The current situation in society show lack of balance of the increasing complexity of organizations and lack of ability in organizations predict and deal with these changes and their complexity. SEMs to counter the environmental threat and the potential opportunities they have to know their internal capacities, repair their weaknesses and strengths in the social interaction between worthy and 
fruitful manner for most managers and leaders as a key organizational change management is increasingly important. Innovation ecosystem is image of future vision that offers their followers. Because such leaders are able to form a clear vision and requirements, may be able to motivate employees to participate in the landscape and subordinates to do the work raises more than expected. The process of innovation ecosystem in the organization and running of innovation capabilities implement the appropriate entrepreneurial process. If entrepreneurship is related to innovation, the need for appropriate innovation style should be adopted to prepare the conditions for entrepreneurial climate, where managers, use appropriate innovation style cannot assume any environment and provide the necessary conditions for the presence of creative people and entrepreneurs. Considering the newness of the issues related to ICTs in the discussion of SME in the world and the newer ones in our country, there is a significant gap in research and applied research projects in this country. In the college campus, very few theses have addressed the subject of a single review of each of the combined research segments of the research, and few who have little to do with the subject or have focused on a particular industry, or whether to study the advantages, disadvantages, constraints and barriers to the realization of the ecosystem of entrepreneurship and innovation, or the communication and information technology, or small and medium enterprises. For this purpose, in this research, we tried to create an entrepreneurial ecosystem to design each domain of the innovation ecosystem, and the innovation and technology of communication and information and startup to the usual entrepreneurship ecosystems as we added the three domains needed to achieve modern technologies and global markets and effective competition in the era of information and communication technologies, explaining these functions and not the process, in the end, our innovative design for ecosystems of innovation and entrepreneurship based on communication technology we got information.

The results showed that innovation ecosystem components (innovation by startup, entrepreneurship, technology, and digital innovation) influence on the development of entrepreneurial attitudes in the small and medium-sized enterprises in ICT industry.

\section{References}

Anderson, R.W., Acur, N., Corney, J., (2018). How do SMEs use open innovation when developing new business models? In Vanhaverbeke, W., Frattini, F., Rojakkers, N., Usman, M. (Eds.), Researching Open Innovation in SMEs, pp. 179-209 
Arabiun, A \&, .Shaye Sani, M (2016). Factors affecting entrepreneurial culture and promoting creativity and innovation in government agencies. Rome, Italy: www.3icm21.com.

Bogers, M., Zobel, A.-K., Afuah, A., Almirall, E., Brunswicker, S., Dahlander, L., Frederiksen, L., Gawer, A., Gruber, M., Haefliger, S. and others, (2017). The open innovation research landscape: established perspectives and emerging themes across different levels of analysis. Industry and Innovation. 24(1), 8-40.

Brunswicker, S., Van de Vrande, V., (2014). Exploring open innovation in small and medium-sized enterprises. In Chesbrough, H., Vanhaverbeke, W. West, J. (Eds.), New Frontiers in Open Innovation. Oxford University Press, Oxford, pp. 135-156.

Dong-ll Shin (2017). An exploratory study of innovation strategies of the internet of things SMEs in South Korea", Asia Pacific Journal of Innovation and Entrepreneurship, Vol. 11 Issue: 2, pp.171-189, https://doi.org/10.1108/APJIE-08-2017-025

Giudici G., Rossi-Lamastra, C., (2018). Crowdfunding of SMEs and startups: when open investing follows open innovation. In Vanhaverbeke, W., Frattini, F., Rijacker, N., Usman, M. (eds.), Researching Open Innovation in SMEs.

Holgersson, M., Granstrand, O., Bogers, M., (2017). The evolution of the intellectual property strategy in innovation ecosystems: uncovering complementary and substitute appropriability regimes. Long Range Planning. Forthcoming

Kapoor, R. and Adner, R. (2015). Innovation ecosystems and the pace of substitution: reexaminingtechnology S-Curves. Strategic Management Journal, Vol. 37 No. 4, pp. 625648.

Muller, P., Caliandro, C., Peycheva, V., Gagliardi, D., Marzocchi, C., Ramlogan, R. and Cox, D. (2015). Annual report on European SMEs. European Commission.

Ndemo, (2016). Enabling an Inclusive Innovation Ecosystem and SME Development in Kenya: The Role of ICTs. 10.1057/978-1-137-60168-1_3.

Pop, O.M., Roijakkers, N., Rus, D., Hins, M. (2018). The link between entrepreneurial attributes and SME ecosystem orchestration: a case from the Dutch HR services industry. In Vanhaverbeke, W., Frattini, F., Roijakkers, N., Usman, M. (Eds.), Researching Open Innovation in SMEs.

Radziwon, Agnieszka and Bogers, Marcel (2018). Open Innovation in SMEs: Exploring Inter-Organizational Relationships in an Ecosystem (April 13, 2018). Technological Forecasting and Social Change, 2018, Forthcoming. Available at SSRN: https://ssrn.com/abstract $=3164950$

Radziwon, A., Bogers, M. Bilberg, A. (2017). Creating and capturing value in a regional innovation ecosystem: a study of how manufacturing SMEs develop collaborative solutions. International Journal of Technology Management. 75(1-4), 73-96.

Rindfleisch, A., O’Hern, M., Sachdev, V., (2017). The digital revolution, 3D printing, and innovation as data. Journal of Product Innovation Management. 34(5), 681-690. 
Saguy, I.S. and Sirotinskaya, V. (2014). Challenges in exploiting open innovation full potential in the food industry with a focus on small and medium enterprises (SMEs). vol. 38, pp. 136-148, 2014. Trends in Food Science \& Technology ,(1) 40pp. 136-148.

Scaringella, L., Radziwon, A., (2018). Innovation, entrepreneurial, knowledge, and business ecosystems: old wine. Technological Forecasting and Social Change. Forthcoming.

Theyel, N. (2013). Extending open innovation throughout the value chain by small and medium-sized manufacturers. International Small Business Journal 31 (3 ,(pp. 256-274.

Usman, M., Roijakkers, N., Vanhaverbeke, W., Frattini, F., (2018). A systematic review of the literature on open innovation in SMEs. In Vanhaverbeke, W., Frattini, F., Roijakkers, N., Usman, M. (Eds.), Researching Open Innovation in SMEs.

Verbano, C., Crema, M. and Venturini, K. (2015). The identification and characterization of open innovation profiles in Italian small and medium-sized enterprises .Journal of Small Business Management 53 (4), pp. 1052-1075.

Wynarczyk, P., Piperopoulos, P. and McAdam, M. (2013). Open innovation in small and medium-sized enterprises: an overview. International Small Business Journal 31 (3), pp. 240-255. 